\title{
Etnomatematika pada Produk Kerajinan Besi di Desa Wuluhan Jember sebagai Bahan Membuat Paket Soal Matematika Kelas XI
}

Author:
Hendrik Win Istiawan ${ }^{1}$
Erfan Yudianto $^{2}$
Titik Sugiarti $^{3}$
Affiliation:
1,2,3 University of Jember, East
Java, Indonesia
Corresponding author:
Hendrik Win Istiawan,
henjek@ gmail.com
Dates:
Received: $24 / 2 / 2021$
Accepted: $2 / 3 / 2021$
Published: $16 / 3 / 2021$

\section{Author:}

Hendrik Win Istiawan

Erfan Yudianto ${ }^{2}$

${ }^{1,2,3}$ University of Jember, East

Java, Indonesia

Corresponding author:

Hendrik Win Istiawan,

Received: 24/2/2021

Accepted: 2/3/2021

Published: 16/3/2021

\begin{abstract}
Abstrak. Ethnomatematics digunakan sebagai mode, gaya, dan teknik "tics" untuk menggambarkan, memahami, dan berurusan dengan lingkungan alam dan "mathema" budaya dalam sistem budaya yang berbeda "ethnos". Artinya etno-matematika berfungsi sebagai jembatan antara matematika dan budaya dalam masyarakat. Tujuan dari penelitian ini adalah mendeskripsikan etnomatematika yang terkandung dalam produk kerajinan besi. Jenis penelitian ini adalah penelitian kualitatif dengan pendekatan etnografi. Ada dua mata pelajaran dalam penelitian ini, S1 sebagai pemilik dan pembuat produk kerajinan besi, dan S2 sebagai pembantu dalam menyelesaikan pembuatan produk kerajinan besi. Metode yang digunakan dalam pengumpulan data adalah observasi, wawancara, dan dokumentasi. Penelitian ini berfokus pada pengamatan etnomatematika yang terkandung pada produk kerajinan besi yang meliputi konsep bangun datar, bangun ruang, garis sejajar, elips, parabola, kongruensi dan kekongruenan. Etnomatematika pada penelitian ini hasil akhir akan dibuat sebagai paket soal matematika untuk siswa kelas XI.
\end{abstract}

Kata kunci: metode pembelajaran mind mapping, jenis kelamin, hasil belajar

\begin{abstract}
Ethnomatematics are used as modes, styles, and techniques of "tics" to describe, understand, and deal with the natural environment and cultural "mathema" in different cultural systems "ethnos". This means that ethnomathematics functions as abridge between mathematics and culture in society. The purpose of this research is todescribe the ethnomatematics contained in iron handicraft products. This type of research is a qualitative research with an ethnographic approach. There are two subjects in this study, SI as the owner and maker of iron handicraft products, and S2as a helper in completing the manufacture of iron handicraft products. The methods used in data collection are observation, interviews, and documentation. This research focuses on observing ethnomatematics contained in iron handicraft products which include the concept of flat shapes, space shapes, parallel lines, ellipses, parabolas, congruence and kekongruenan. Ethnomatematics in this study the final results will bemade as a package of math problems for class XI students.
\end{abstract}

Keywords: Etnomatematika, produk kerajinan besi, paket soal matematika

\section{J0MF OL Copright:}

This work is licensed under a Creative Commons Attribution-ShareAlike 4.0 International License.

Read online:

https://jurnal.unej.ac.id/index.php/JOMEAL/index

or scan barcode beside.

How to cite this article:

Istiawan, H., Yudianto, E., \& Sugiarti, T. (2021). Etnomatematika pada Produk Kerajinan Besi di Desa W wuluhan Jember sebagai Bahan Membuat Paket Soal Matematika Kelas XI. Journal of Mathematics Education and Learning, 1(1), 9-19. Retrieved from https://jurnal.unej.ac.id/index.php/JOMEAL/article/ view/24371 


\section{Pendahuluan}

Pendidikan merupakan ilmu penting dalam kehidupan sehari-hari yang menghasilkan suatu hasil yang lebih baik daripada tidak dengan didasarkan denganhal tersebut (Bird, 2005). Salah satu ilmu pengetahuan dan seni yang pesat berkembangnya dan mendukung dalam berbagai cabang ilmu pendidikan yaitu dalam bidang matematika. "Mathematics is the gate and key of the sciences" yang berarti matematika tidak hanya berfungsi sebagai kunci tetapi juga merupakan gerbang bagi perkembangan ilmu pengetahuan (Fiyany, Mawardi, \& Astuti, 2018). Matematika merupakan ilmu struktur yang mencakup dalam perhitungan, pengukuran, dan penggambaran objek. Pengukuran dan penggambaran objek dalam matematika dipelajari mendalam padasalah satu cabang ilmu yaitu geometri (Hartoyo, 2012).

Geometri adalah bagian dari matematika yang menyelidiki tentang titik, garis, bidang, dan ruang. Titik merupakan konsep pangkal yang kemudian digunakan untuk membentuk garis dan garis yang akan menyusun sebuah bidang. Keempat konsep ini yang menjadi dasar pengembangan geometri-geometri. Salah satu pembahasan geometri yang dikaitkan dengan prinsip aljabar adalah geometri analitika. Geometri analitika dibagi menjadi analitika bidang dan analitika ruang. Irisan menjadi salah satu kajian dalam geometri analitika bidang (Huda, 2018). Geometri kerap hubungannya dengan ilmu kongkret dan abstrak. Geometri merupakan kajianyang paling dekat dengan siswa karena berhubungan dengan visualisasi (Karim \& Hidayanto, 2014).

Matematika selalu memegang kunci utama dalam kurikulum sekolah karena matematika dianggap sebagai pengetahuan yang tidak dapat dipisahkan dari seseorang. Kemampuan yang berkaitan dengan matematika seperti kemampuan berpikir logis, analitis, sistematis, kritis, inovatif, dan kreatif, serta kemampuan berkerja. Kemampuan ini diperlukan agar siswa dapat memperoleh, mengelola, dan memanfaatkan informasi untuk hidup lebih baik pada keadaan yang selalu berubah (Kemendikbud, 2015). Penggunaan matematika dalam kehidupan sehari-hari ini tentu menciptakan suatu aktivitas tertentu yang akan menjadi budaya dalam masyarakat. Budaya yang ada dalam suatu masyarakat pasti berbeda dengan masyarakat lainnya. Budaya mempengaruhi segala bentuk kebiasaan dan aktivitas yang ada sehingga konsep matematika yang ada juga berbeda (Kemendikbud, 2015).

Etnomatematika digunakan sebagai mode, gaya, dan teknik "tics" menjelaskan, memahami, dan menghadapi lingkungan alam dan budaya "mathema" dalam sistem budaya yang berbeda “ethnos” Ngiza, Susanto, \& Lestari, 2015). Pendekatan materi matematika terhadap siswa menuntut guru selalu aktif menggali sumber-sumber belajar di sekitar lingkungan belajar siswa. Penggalian sumber belajar seperti ini diharapkan mampu mengoptimalkan pembelajaran dengan 
menuangkannya ke dalam media untuk menyampaikan suatu materi pada mata pelajaran matematika salah satu hal yang dekat dengan siswa adalah bermain (Susanto, Meifiani, \& Hidayat, 2017).

Salah satu budaya yang dapat dipelajari dengan memperhatikan konsep matematika didalamnya yaitu produk yang dihasilkan oleh pengrajin besi. Produk pengrajin besi sudah sangat familiar dikalangan masyarakat karena setiap hari pasti dilihat. Contoh produk pengrajin besi antara lain pisau, clurit, pedang, cangkul danparang. Manfaat produk kerajinan besi sangatlah banyak terutama untuk keperluanrumah tangga dan dapat dijadikan kebutuhan primer. Eksplorasi tentang etnomatematika pada produk kerajinan besi sehingga bisa diintegrasikan ke dalam pembelajaran matematika di sekolah khususnya geometri. Dari uraian di atas, Latarbelakang dilakukannya penelitian ini bertujuan untuk mengetahui etnomatematika yang ada pada produk Kerajinan Besi di Desa Wuluhan Jember dan menyusun produk hasil penelitian berupa paket soal matematika yang berkaiatan dengan etnomatematika pada produk kerajinan besi di Desa Wuluhan untuk kelas XI.

\section{Metode Penelitian}

Jenis penelitian yang digunakan dalam penelitian ini adalah penelitian kualitatif. Penelitian kualitatif berarti proses eksplorasi dan memahami maknaperilaku individu dan kelompok, menggambarkan masalah sosial atau masalah kemanusiaan. Penelitian ini menggunakan jenis penelitian kualitatif karena bermaksud untuk mengetahui etnomatematika pada produk pengrajin besi. Supayamempermudah mencapai tujuan penelitian, maka langkah pertama yang dilakukan adalah pemilihan tempat dan subjek penelitian. Daerah yang akan dijadikan tempatpenelitian ini adalah Desa Wuluhan, kabupaten Jember. Subjek penelitian adalah pembuat, pemilik dan pengguna sebagai objek yang dituju untuk diteliti olehpeneliti di Desa Wuluhan, Jember. Subjek dalam penelitian ini ada 2 orang yaitu S1 sebagai pemilik dari tempat produksi sekaligus sebagai pembuat kerajinan besi, danS2 sebagai pekerja dan pembuat kerajinan besi. Metode pengumpulan data yang digunakan yaitu observasi, wawancara, dan dokumentasi.

Selanjutnya langkah kedua yang dilakukan adalah menyusun instrumen penelitian yang nantinya digunakan sebagai pedoman observasi dan pedomanwawancara. Langkah ketiga adalah menyertakan draf instrumen yang isinya terdapat rancangan dan konsep dari suatu instrumen yang akan diberikan kepada validator. Langkah berikutnya adalah mengenai validasi draft instrument pedomanobservasi dan pedoman wawancara yang divalidasi oleh validator. Selanjutnya langkah kelima mengenai instrument yang sudah dinyatakan valid oleh validator menuju ke tahap selanjutnya. Tahapan selanjutnya adalah pengumpulan data mengenai hasil yang diperoleh dari observasi, wawancara, dan dokumentasi. Penelitian ini mengamati mengenai etnomatematika yang terdapat pada produk kerajinan besi. Selain observasi, penelitian ini melakukan juga tahapan wawancarayang tujuannya digunakan untuk mendapat data lebih detail dari hasil hasil observasi sebelumnnya. Tahapan ketujuh membahas tentang analisis data yang didapatkan sesuai dengan kajian masalah dan tujuan penelitian. Tahapan kedelapanyaitu menyusun paket soal matematika mengenai konsep matematika yang diperoleh dari data mengenai produk kerajinan besi di Rumah 
Produksi Kerajinan Besi Wuluhan. Tahapan terakhir yaitu menyimpulkan hasil analisis data yang telahdiperoleh dari tahapan-tahapan sebelumnya.

\section{Hasil dan Pembahasan}

Berdasarkan hasil observasi dan hasil wawancara dengan narasumber terhadap 2 subjek penelitian yaitu pemilik dan pekerja dari tempat kerajinan besi Desa Wuluhan Jember, terdapat etnomatematika yang muncul pada beberapa produk kerajinan besi. Pada penelitian ini ditemukan beberapa konsep dan unsur geometri yaitu bangun datar, bangun ruang, tranformasi geometeri, elips, garis sejajar, parabola, sudut, kesebangunan dan kekongruenan.

\section{A. Konsep Bangun Datar}

Pelajaran matematika diantaranya yaitu persegi, persegi panjang, belah ketupat,lingkaran dan segi banyak (polygon). Penelitian ini terfokus pada etnomatematika yang yang muncul pada produk kerajinan besi diantaranya pada permukaan produk,bentuk produk kerajinan dibagi juga menjadi beberapa yaitu bagian ujung, tengah dan tangkal. Berdasarkan hasil penelitian pada Produk Kerajinan Besi, terdapat bangun datar yaitu diantaranya persegi panjang, lingkaran, dan segitiga.

P10105 : Apakah pada setiap produknya terdapat bentuk bangun datar?

Semisal seperti persegi, persegi panjang, lingkaraan, dan lainnyaS10105 : Ada mas, tapi tidak semua produk terdapat bangun tersebut

P10106 : Jadi semisal pisau itu terdapat unsur persegi, segitiga, lingkarang ya Pak?

S10106 : Iya mas, tapi itu harus lebih detail lagi jika ingin mencari bangun yang terdapat didalamnya

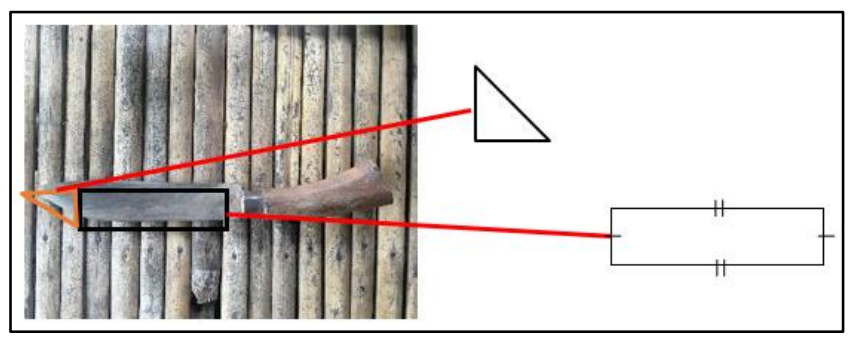

Gambar 1. Bentuk Segitiga dan Segiempat pada Permukaan Produk Pisau

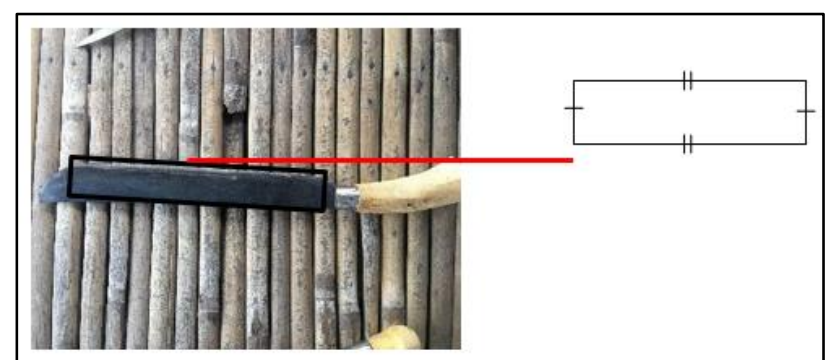

Gambar 2. Bentuk Bagian Lingkaran dan Segiempat pada Permukaan Parang 


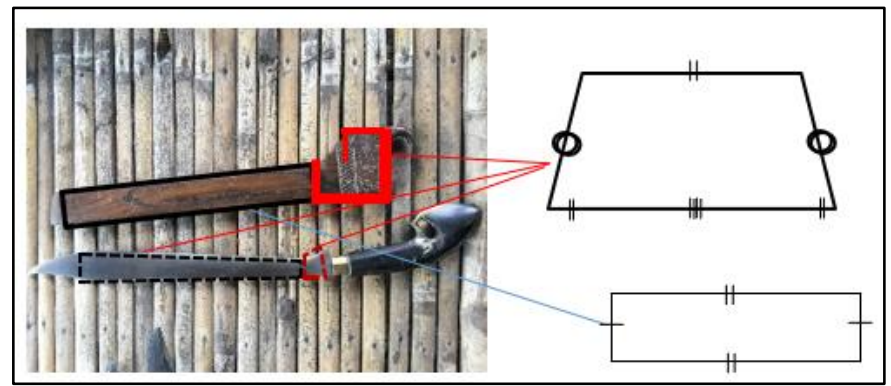

Gambar 3. Bentuk Trapesium dan Segiempat pada Permukaan Pedang

Konsep bangun datar terdapat pada beberapa gambar yang sudah disajikan. Pada beberapa produk kerajinan besi terdapat konsep bangun datar. Bangun datar diperoleh dari bentuk permukaannya yang terbuat dari lempengan besi.

\section{B. Konsep Bangun Ruang}

Cuplikan sebelumnya mengenai bangun datar, ada pula bangun ruang yang dipelajari pada jenjang sekolah. Bangun ruang matematika yaitu bentuk bangun mempunyai volume atau isi. Pada penelitian ini, bangun ruang muncul pada bentukbentuk produk kerajinan besi. Beberapa konsep yang tertera berhubungan dengan etnomatematika selanjutnya dijelaskan dengan dihubungkan gambar dari produk akhir kerajinan besi.

P20202 : Jadi pada bentuk keseluruhan produk terdapat konsep bangun ruang?

S20202 : Iya mas tapi bangun ruang yang terdapat pada produk secara keseluruhanhanya terdapat pada bangian pegangannya mas

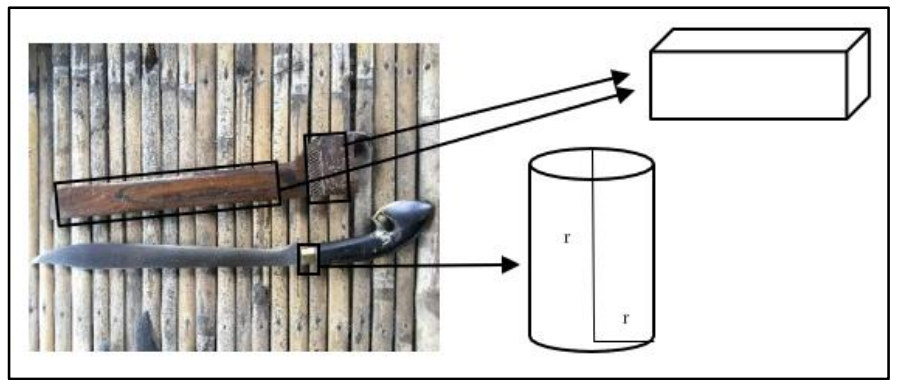

Gambar 4. Bentuk Tabung Bagian Tengah dan Balok pada Kerajinan Parang

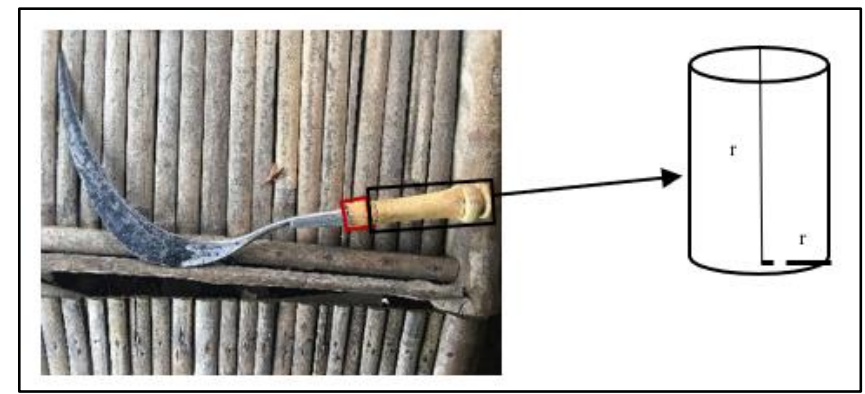

Gambar 5. Bentuk Tabung Bagian Tangkai pada Kerajinan Clurit 


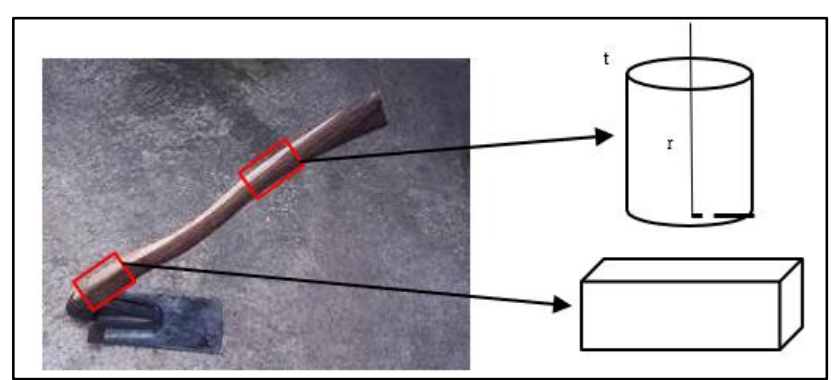

Gambar 6. Bentuk Balok dan Tabung Bagian Tangkai pada Kerajinan Cangkul

Hasil wawancara pada produk kerajinannya terdapat bentuk bangun datar sudah disajikan sebelumnya. Bangun datar diantara balok, dan tabung. Bentuk pegangan yang terdapat dapat mempermudah petani dalam kegiatan bertani sehari-hari.

\section{Konsep Garis Sejajar}

Dua garis yang dikatakan sejajar jika dan hanya jika kedua garis yang tersedia tidak mempunyai titik sekutu. Garis AB dan EF pada gambar 4.10 merupakan garis sejajar. Jika kedua garis diperpanjang sampai ke ujung kiri atau ke ujung kanan garis tersebut tidak akan saling bertemu dan berpotongan. Garis sejajardapat disimbolkan dengan '//'.

P10302 : Untuk produk Bapak lebih seperti apa?

S10302 : Kalau dari mengkilapnya kami tidak merekoendasikan karena untukketajaman kurang, kami lebih memilih yang hitam, biasanya untuk yang mengkilap hanya untuk menakuti tapi untuk ketajaman kurang

P10303 : Jika dilihat secara langsung, menghasilkan garis-garis sejajar bagaimanapembuatannya?

S10303 : Untuk itu sewaktu pengasahan dilakukan secara searah mas, jadi tidaksembarang kalau tidak searah hasilnya tidak aturan mas

Berdasarkan hasil wawancara tersebut, diketahui bahwa S1 dalam hasil akhir dari produk terdapat bentuk garis sejajar pada permukaan setiap produk yang dihasilkan. Motif yang terdapat dari produk dapat dilihat dari permukaannya,namun kebanyakan dari berbagai produk di semua daerah pada permukaannya terdapat garis sejajar. Garis sejajar yang terbentuk disebabkan oleh cara S1 melakukannya hanya dengan searah hingga menghasilkan garis seperti itu.

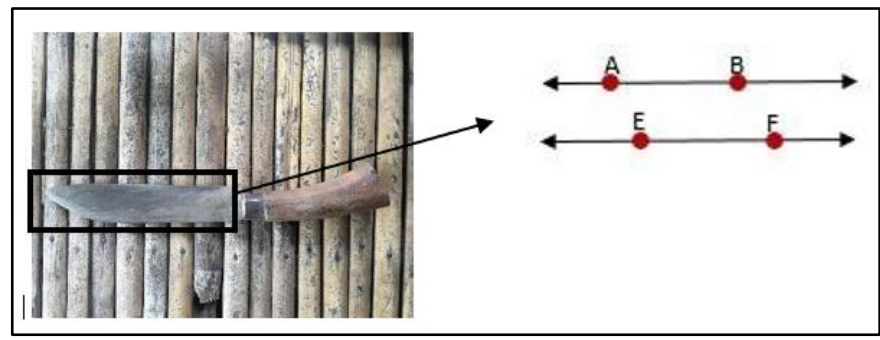

Gambar 7. Ilustrasi Bentuk Garis Sejajar pada Permukaan Lempengan Pisau

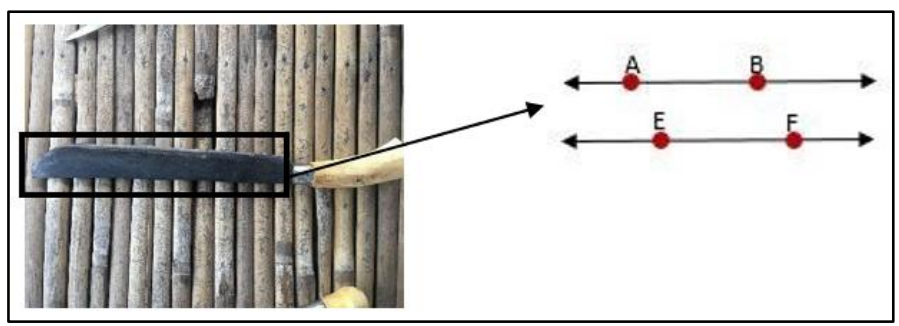

Gambar 8. Ilustrasi Bentuk Garis Sejajar pada Permukaan Lempengan Kapak 


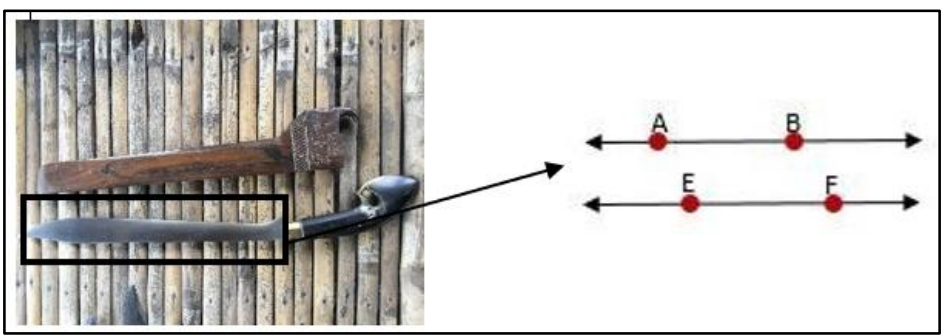

Gambar 9. Ilustrasi Bentuk Garis Sejajar pada Permukaan Lempengan Pedang

\section{Konsep Elips}

Garis yang membagi bentuk elips memiliki panjang yang berbeda dan salahsatunya lebih panjang. Hasil dari ditariknya garis yang memotong secara vertical dan horizontal membentuk sudut siku-siku. Ruangan dalam elips terbagi menjadi 4bagian yang sama besar dan tali busur yang sama panjang. Elips dibedakan menjadidua yaitu elips horizontal dan elips vertikal.

P10404 : Jika dilihat dari hasilnya pada produk parang bagian ujungnya runcingtapi bentuknya seperti elips jika dalam ilmu matematika Pak

S10404 : Kalau saya sekedar membuat saja mas perihal bentuk yang sampai detailseperti itu saya kurang paham mas berdasarkan hasil wawancara dapat diperoleh jika bagian ujung pada setiap produkberbentuk runcing. Pada beberapa bentuk produknya banyak yang memiliki bentuk lancip hanya 1 produk yang berbeda, meskipun untuk bentuk lancipnya tidak sama. Pada produk parang dapat disimpulkan jika bentuknya terdapat konsep elips.

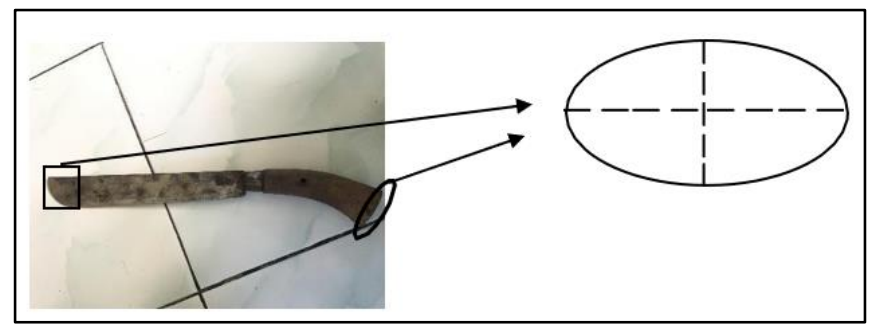

Gambar 10. Bentuk Elips pada Ujung dan Tangkal Pegangan Kerajinan Parang

Bentuk elips yang dihasilkan dari hasil observasi terdapat pada ujung kapak dan pada tangkal pegangan kapak. Bentuk terbentuk tidak semua utuh berbentuk elips.pembentukan elips pada saat pengerjaan dengan cara menempa hingga tipis dan ujung pada parang dibentuk menyerupai seperempat elips bertujuan untuk kebutuhan kapak semestinya. Pangkal tangkal pegangan kapak sendiri berbentuk elips dibentuk secara tidak sengaja oleh pekerja.

\section{E. Konsep Parabola}

Bentuk parabola yang dipelajari pada jenjang sekolah SMA dan sederajat dikenal oleh siswa sukar untuk dipahami karena ada hubungannya dengan grafik, titik dalam kurva. Pengertian bentuk parabola dapat diartikan bentuknyamenyerupai U dan kurva yang dibuatnya saling simetris, parabola dikaitkan denganhubungannya dengan titik dan garis.

P10501 : Bagaimana jika dicerminkan beberapa produk kerajinan yang dihasilkan dapat menghasilkan bentuk parabola?

S10501 : Bentuk parabola itu seperti apa ya mas?

P10502 : Bentuk parabola itu seperti selang yang digunakan para tukang bangunanuntuk mengukur ketinggian yang sama dari sisi ujung kiri ke sisi yang lainnya. Jadi bentuknya bias melengkung atau cekung gitu Pak? 
S10502 : Menurut saya jikasepintas saya kurang paham mengenai hal tersebut mas

Hasil dari wawancara yang telah dilakukan dapat disimpulkan bahwa pencerminan dari produk kerajinan, menurut pekerja belum ditemukan mengenai pencerminan secara parabola. Bentuk dari beberapa produk memiliki bentuk yang sangat berbeda jadi untuk mendefinisikan apakah ada pencerminan atau tidak haruslebih mendetail lagi melihatnya.

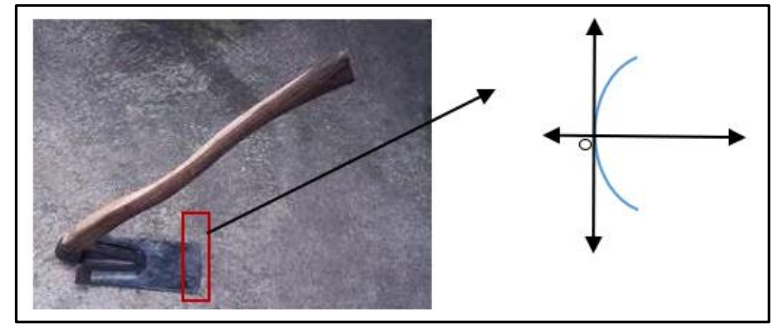

Gambar 11. Ilustrasi Bentuk Parabola pada Ujung Besi Kerajinan Cangkul

Berdasarakan hasil wawancara dengan S1, S1 tidak memahami jika bentuk yang terdapat pada ujung besi cangkul merupakan bentuk parabola yang termasuk dalam pembelajaran matematika. Bentuk parabola tersebut merupakan parabola sederhana yang melewati titik $(0,0)$. Pembentukan parabola dibentuk secara tidak sengaja oleh S1, yaitu S1 hanya mempertimbangkan fungsi dan kegunaan cangkul untuk jebutuhan petani. Menurut S1 bentuk seperti itu dalam bertani bertujuan untuk mempermudah petani dalam menggemburkan tanah dan melubai tanah supaya lebih mudah untuk diproses tanahnya sesuai dengan apa yangakan ditanam oleh petani.

\section{F. Konsep Sudut}

Sudut sangat tidak asing untuk siswa karena sudut sudah dipelajari sejak siswa pada jenjang SD hingga SMA/Sederajat tetap dipelajari mengenai konsep matematika yang satu ini. Definisi sudut adalah jarak yang terbentuk pada 2 garis lurus yang bertemu pada satu titik. Secara umum sudut memiliki beberapa macam yaitu sudut lancip, siku-siku, tumpul dan untuk satuan sudut yaitu derajat. Sudut terdapat pada berbagai macam bentuk bangun datar yang dipelajari dalam ilmu matematika.

P20603 : Apakah membentuk sudut lancip atau sudut tumpul jika diilustrasikandengan konsep matematika?

S20603 : Kurang begitu paham mas kalau mengenai membentuk hal tersebut

P20604 : Jika untuk pelaksanaannya apakah Bapak tahu kalau membentuk sudut sewaktu tangan memukul

S20604 : Tidak tahu sama sekali mas, terpenting dari kami itu bekerja selesai danberharap hasilnya maksimal

Menurut hasil wawancara yang telah dilakukan dengan S2 dapat disimpulkan bahwa dalam melakukan pukulan waktu proses mempipihkan lempengan besinya tidak memerlukan waktu yang cukup panjang dan pada prosesnya terbentuk sudut.

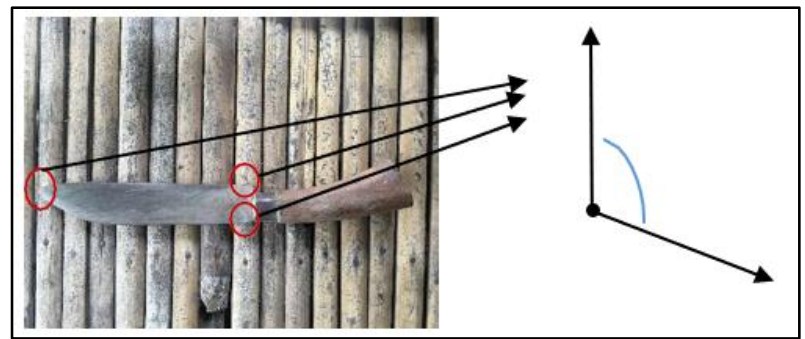

Gambar 12. Ilustrasi Bentuk Sudut pada Kerajinan Pisau 


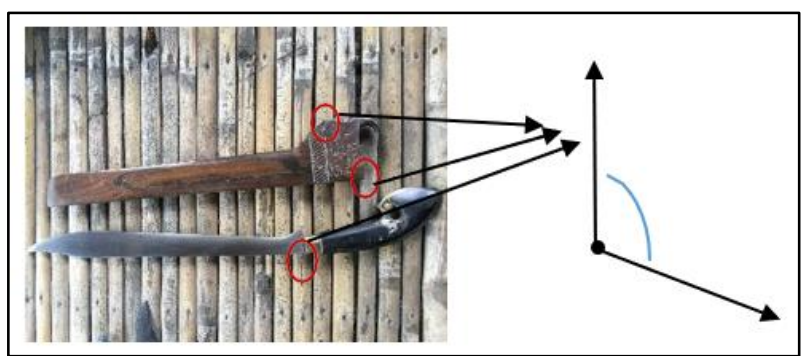

Gambar 13. Ilustrasi Bentuk Sudut pada Kerajinan Pedang

Berdasarakan hasil cuplikan observasi dan wawancara dengan pemilik mengenai beberapa bentuk kerajinan yang memiliki sudut, pemilik mengatakan bahwa untuk sudut terbentuk tidak begitu detail dalam melihat dan memahami suduttersebut. Pada dasarnya sudut yang terbentuk memang sudah ikut dari bentuk kerajinan dibuat tanpa mempertimbangkan didalamnya akan terbentuk sudut secaraumum. Bentuk sudut yang terbentuk dapat didapatkan dengan proses yang tidak sengaja tetapi secara umum bentuknya seperti itu.

\section{G. Konsep Kesebangunan dan Kekongruenan}

Kesebangunan dan kekongruenan dalam bidang matematika dipelajari padajenjang SMP, SMA/Sederajat. Pengertian kesebagunan yaitu bentuk 2 bangun dataryang memiliki sudut-sudut sama besar. Kekongruenan adalah bentuk bangun dataryang memiliki bentuk, ukuran yang sama, perbandingan sama persis, jadi panjang,lebar, tinggi, luas, dan volume sama persis.

P10703 : Semisal tidak ada ukuran khusus dari pelanggan, apakah tetap ada ukurantetap dari tempat kerajinan ini Pak?

S10703 : Ada mas, untuk contoh produk pisau panjang awal $20 \mathrm{~cm}$ mas, setelahitu jadi 2 dan didalamnya diberi baja sesuai dengan ukuran lempengan setelah dilipat

P10704 : Jadi pada bentuk hasil jadi beberapa produk menghasilkan bentuk yangsama dan dalam ilmu matematika disebut kesebangunan dan kekongruenan Pak

S10704 : Iya mas maaf saya tidak perihal dihubungkan dengan konsep matematika

Berdasarkan cuplikan wawancara dengan pengrajin, didapatkan informasi mengenai ukuran awal lempengan besi yang digunakan yaitu sepanjang $20 \mathrm{~cm}$ danitu digabungkan dengan baja sesuai dengan ukuran. Pada hasilnya dapat diketahui jika hasilnya dari beberapa produk terdapat konsep kesebangunan dan kekongruenan.

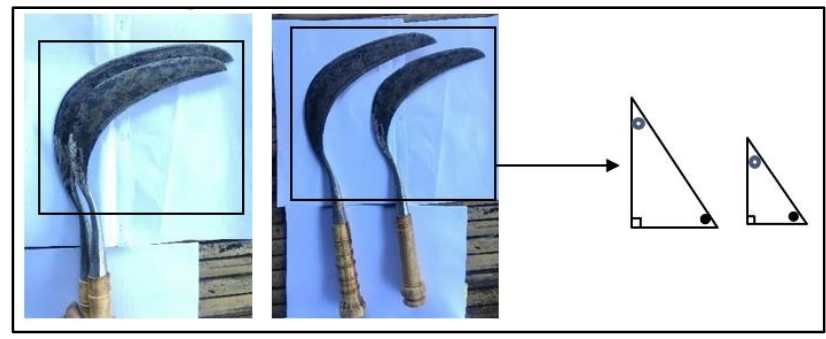

Gambar 14. Ilustrasi Bentuk Kesebangunan pada Kerajinan Clurit 


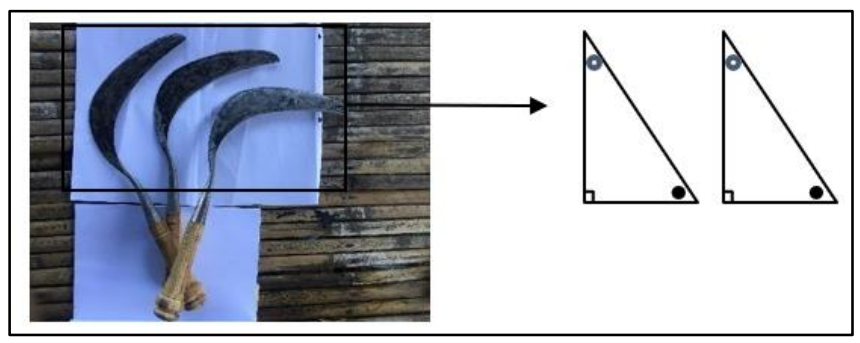

Gambar 15. Ilustrasi Bentuk Kesebangunan pada Kerajinan Clurit

Berdasarkan cuplikan hasil observasi dan wawancara dengan S2, bentuk yang dihasilkan pada proses pembuatan beberapa produk kerajinan besi secara tidak sengaja menghasilkan bentuk dan ukuran yang sama besar. Patokan ukuran untuk pembuatan produk tidak ada ketentuan inti, jadi dalam tahap pembuatan hanya mengandalkan kebiasaan dan keseringan membutan kerajinan. Jika dilihat dari hasilnya, observer dapat mengamati jika sebagian besar produk kerajinan besi yang dihasilkan menghasilkan bentuk dan ukuran yang kekongruenan. Pada beberapa produk ada pula bentuk sama tetapi ukurannya tidak sama.

\section{Kesimpulan}

Berdasarkan hasill analisis dan pembahasan, dapat disimpulkan bahwa terdapat entomatematika dan terdapat konsep atau unsur geometri pada produk kerajinan besi dirumah produk desa Wuluhan. Etnomatematika muncul pada saat hasil produk kerajinannya sudah jadi (pisau, parang, pedang, clurit, dan cangkul), yang didalamnya terdapat unsur atau konsep geometri secara umum yang terdapat pada produk kerajinan besi yaitu bangun ruang, bangun datar, garis sejajar, elips, parabola, sudut, kesebanggunan dan kekongruenan. Etnomatematika pada konsep bangun ruang yang terdapat pada (pisau, parang, pedang, clurit dan cangkul) memiliki ukuran yang berbeda-beda sesuai dengan bentuk dan ukuran produkkerajinan masing-masing. Konsep bangun ruang banyak dikaitkan dengan ganggangatau pegangan dari produknya. Etnomatematika pada konsep bangun ruang yang terdapat pada (pisau, parang, pedang, clurit dan cangkul) adalah segitiga, lingkaran, persegi. Dalam pembuatan bentuk tersebut, pengrajin secara tidak sengaja hhingga muncul bentuk yang erat kaitannya dengan konsep geometri.

Etnomatematika pada konsep garis sejajar muncul pada (pisau, parang dam pedang) terbentuk karena aktivitas pembuatan pengrajin dengan menggunakanampelas dengan cara menggosok secara searah berulang-ulang. Etnomatematika lainnya pada garis sejajar muncul pada (pisau, parang dam pedang) terbentuk karenaaktivitas pembuatan kerajinan dengan menggunakan ampelas dengan cara menggosok secara searah berulang-ulang. Motif ini memberikan kesan mengkilap untuk menarik pembeli.

Produk (pisau, parang, pedang dan cangkul) merupakan etnomatematika yang ada kaitannya dengan sudut. Sudut yang diketahui pada produk kerajinan termasuk pada materi kesebanguna matematika. Kesebangunan muncul pada produkkerajinan clurit karena dapat dihubungkan dengan konsep kekongruenan yangterdapat pada (pisau, parang, pedang, clurit dan cangkul) karena pada sebagian besar produk yang dihasilkan pada bentuk dengan ukuran yang sama dapat disimpulkan sebagai kesebangunan. 


\section{Daftar Pustaka}

Bird, J. (2005). Basic Engineering Mathematics (4th ed.). Routledge.

Fiyany, F. N., Mawardi, \& Astuti, S. (2018). Keefektifan Model PembelajaranBamboo Dancing dan Jigsaw Ditinjau dari Hsail Belajar Matematika Siswa Kelas 4 SD. Teori dan Aplikasi Matematika, 2(1), 76-86.

Hartoyo, A. 2012. Eksplorasi Etnomatematika pada Budaya Masyarakat Dayak Perbatasan Indonesia-Malaysia Kabupaten Sanggau Kalbar. Jurnal Penelitian Pendidikan. 13(1):14-23.

Huda, N. T. (2018). Etnomatematika pada Bentuk Jajanan Pasar di Daerah Istimewa Yogyakarta, 2(2), 217-232.

Karim, M. A., \& Hidayanto, E. (2014). Modul 1 Bangun Datar. Pendidikan Matematika II (pp. 143). Jakarta: Universitas Terbuka.

Kemendikbud. 2015. Matematika, SMA/SMK Kelas XI Semester I. Jakarta: Pusat Kurikulum dan Perbukuan, Balitbang, Kemdikbud.

Ngiza, L. N., Susanto, dan N. D. S. Lestari. 2015. Identifikasi Aktivitas Etnomatematika Petani pada Masyarakat Jawa Di Desa Sukoreno. Artikel Ilmiah Mahasiswa. I(1):1-6.

Susanto, H. P., Meifiani, N. I., \& Hidayat, T. (2017). Analisis Hubungan Hasil Belajar Geometri Bidang dengan Kemampuan Analitis Mahasiswa pada Mata Kuliah Geometri Analitik Bidang. JPMP, 5(2), 159-164. 